\title{
Franz Kafka
}

The Necessity of Form 


\section{also by Stanley Corngold}

BOOKS

The Commentators' Despair: The Interpretation of Kafka's

"Metamorphosis"

The Fate of the Self: German Writers and French Theory

EDITED WORKS

Aspekte der Goethezeit (with Michael Curschmann and Theodore Ziolkowski)

Ausgewählte Prosa by Max Frisch

The Metamorphosis by Franz Kafka

Thomas Mann, 1875-1975 (with Richard Ludwig) 


\section{Franz Kafka}

The Necessity of Form

by Stanley Corngold

CORNELL UNIVERSITY PRESS - ITHACA AND LONDON 
Open access edition funded by the National Endowment for the Humanities/ Andrew W. Mellon Foundation Humanities Open Book Program.

Copyright (C) 1988 by Cornell University

All rights reserved. Except for brief quotations in a review, this book, or parts thereof, must not be reproduced in any form without permission in writing from the publisher. For information, address Cornell University Press, Sage House, 512 East State Street, Ithaca, New York 14850, or visit our website at cornellpress.cornell.edu.

First published 1988 by Cornell University Press

Library of Congress Cataloging-in-Publication Data

Corngold, Stanley.

Franz Kafka : the necessity of form.

Includes index.

1. Kafka, Franz, 1883-1924. 2. Authors, Austrian-20th century-Biography. I. Title.

PT2621.A26Z664 $1988 \quad 833^{\prime} .912$ [B] 88-47721

ISBN-13: 978-0-8014-2199-0 (cloth) — ISBN-13: 978-0-8014-9768-1 (pbk.)

The text of this book is licensed under a Creative Commons Attribution-NonCommercial-NoDerivatives 4.0 International License: https://creativecommons.org/licenses/by-nc-nd/4.0/ 
My whole being is directed toward literature; I have followed this direction unswervingly . . . and the moment I abandon it I cease to live. Everything I am, and am not, is a result. . . It is the earthly reflection of a higher necessity.

Franz KafKa, Letters to Felice (19I3)

From the West all content acquires meaning from form only, one's gaze is fixed only on form, courtesy of Flaubert. . . It became the feature of apocalypse: the task of reality pure and simple, the transposition of all substance into form, into the formula.

\section{GotTfried BenN, "Züchtung I"}

He does not live for the sake of his personal life; he does not think for the sake of his personal thoughts. It seems to him that he lives and thinks under the compulsion of a family, which, it is true, is itself superabundant in life and thought, but for which he constitutes, in obedience to some law unknown to him, a formal necessity.

Franz KafKa, The Great Wall of China (1920) 
